\title{
Personal Socio-academic Contributions in Translation and Interpreting Studies
}

\author{
Daniel Gile \\ Université Paris Sorbonne-Nouvelle \\ daniel.gile@yahoo.com
}

\begin{abstract}
Personal socio-academic contributions have been particularly influential in the emergence and early development of TIS (Translation and Interpreting Studies). This is shown through the analysis of three case studies, the Leuven-CETRA-EST lineage, the ESIT-Interpretive Theory paradigm and the birth of the Japan Association for Interpreting (and Translation) Studies. Besides these particularly spectacular and unusual cases in which personal socio-academic contributions played a major role, individual researchers can help break the isolation of small branch-specific TIS communities by organizing face-to-face and online meetings and interaction, and help ensure that the TIS population is renewed through a supportive and inspiring attitude that would give graduating students motivation to engage in research. There is no guarantee that TIS will continue to exist as a disciplinary entity, but what it has gained through its disciplinary existence so far could be useful for future investigations into translation and interpreting.
\end{abstract}

KEYwORDS: Translation and Interpreting Studies (TIS), socio-academic contributions, disciplinary entity, Leuven-CETRA-EST lineage, ESIT-Interpretive Theory paradigm

논문초록: 개인의 사회학문적 기여는 통번역학의 부상 및 초기 발전에 특히 큰 영향을 미쳤다. 이는 루벤-CETRA-EST 계보, ESIT-해석이론 패러다임, 일본통(번)역학협 회의 태동 등 3 가지 사례연구의 분석에서 잘 드러난다. 이처럼 개인의 사회학문적 기 여가 중대한 역할을 한 이례적이고 특히 인상적인 사례 이외에도, 개별 연구자는 대 면 · 온라인 회의 및 소통 기회 마련을 통해 소규모 분파 단위로 구성된 통번역학 공동 
체의 고립을 해소하는 데 도움을 줄 수 있다. 또한 영감을 주고 힘을 북돋는 태도를 바 탕으로 졸업 예정자에게 학문에 대한 동기를 부여함으로써 새로운 통번역학 학자들을 발굴할 수 있다. 앞으로도 통번역학이 단일 독립 학문 분야로 존재할는지 보장할 수 없 으나, 지금까지 독립적 학문으로서 쌓아 올린 성과는 통번역에 대한 향후 연구에 유용 하리라고 본다.

핵심어: 통번역학(TIS), 사회학문적 기여, 독립적 학문, 루벤-CETRA-EST 계보, ESIT-해석이론 패러다임

\section{Introduction}

Usually, the contribution of individual researchers to their discipline is measured by so-called impact factors. The best-known among them are based on the number of citations which mention an author's publications in the literature and the number of his/her publications accepted by highranking peer-reviewed journals - see a general discussion of impact factors in Cameron (2005), and further discussions and specific examples of attempts to develop quantitative indicators in Moed and Halevi (2015) and Grinev (2021). When researchers apply for an academic position or a promotion, invited assessors may also be asked to comment in general terms on the candidates' qualifications and past record, and sometimes on their past and expected contribution to their discipline. By and large, the focus is on their research achievements - in terms of theory, empirical findings and/or methodological innovation.

In this essay, I depart from this traditional focus on research as an intellectual activity and its products, and address what I call its socioacademic aspect: research is conducted by individuals organized in social groups within academic institutions according to social norms and with financial, technological and infrastructural resources (Merton, 1973). They engage in research, but also in activities such as teaching, supervising theses and dissertations, organizing conferences, editing journals and collective volumes, and in activities which are less specific to scientific research such as raising funds and managing the purchase and maintenance of equipment, managing human resources, and communicating with the non-academic world. 
While part of the academic world is run by technicians, financial officers, communications officers, human resource managers and publishers, most of it is run by the academics themselves. It will be argued that in TIS (Translation and Interpreting Studies) and in the disciplines and sub-disciplines that have been emerging around TIS, the socio-academic contribution of some individuals has been particularly important, both in founding the discipline and its sub-disciplines and in shaping their initial evolution over the first few decades.

To illustrate the importance of personal socio-academic contributions in the emergence of TIS, I will focus on two international 'lineages' in the history of TIS, the Leuven-CETRA-EST lineage, and the ESIT-InterpretiveTheory paradigm. I will also present briefly an interesting national case, the foundation of the Japan Association for Interpreting Studies. My hope is that colleagues who know about other cases where personal socio-academic contributions have played an important role, perhaps in Eastern Europe and Asian countries where TIS is emerging, can conduct similar analyses so as to provide a more comprehensive picture of this sociological aspect of the early development of the discipline.

I have chosen the Leuven-CETRA-EST lineage and the ESITInterpretive-Theory paradigm as the first foci of the present analysis for the following reasons:

1. These are arguably the most successful cases of creation of international TIS entities, at least in the 'West', and both have achieved worldwide influence.

2. Both are atypical as disciplinary creations: they resulted from a personal or collective vision of a new discipline, not from a scientific evolution of findings and theories as in the creation of psycholinguistics out of linguistics and psychology, or in the emergence of biochemistry out of biology and chemistry. In addition, as is explained in section 2.2, the initiator and main driving force behind the ESIT-Interpretive Theory paradigm came from the world of interpreting practice, not from academia (see details in WidlundFantini, 2007).

3. I am personally acquainted with most of the main actors in these two lineages and have been involved with $\mathrm{CE}(\mathrm{T}) \mathrm{RA}$ and EST from 
the early 1990s on. This has given me direct access to much reliable information - further clarifications are provided in notes at the end of this paper. On the other hand, I am not a neutral analyst: I have strongly approved the Leuven-CETRA-EST mindset from the start (see Gile, 1994, 1996) and have reservations about some positions on research into translation and interpreting taken by Seleskovitch, the main founder of the ESIT-Interpretive Theory paradigm (Gile, 1990). However, the focus here is on Seleskovitch's remarkable socio-academic contribution and the lasting success of the paradigm among translator and interpreter trainers worldwide, which I acknowledge and highlight. As to her ideas on research, they are explained with citations from one of her own publications (Seleskovitch, 1990) and from a bibliography dedicated to her by one of her followers and admirers, Widlund-Fantini (2007).

After presenting the role of personal socio-academic contributions in the very emergence of TIS in the West and in the foundation of the Japanese Association of Interpreting Studies, I will discuss less spectacular, but nevertheless important socio-academic contributions that help sustain the discipline despite its still fragile institutional status.

\section{A Central Stake: Gaining Recognition for TIS as a Discipline}

According to Popper (1959/2002), science advances as theories are tested, falsified by empirical tests and improved or replaced by other theories; in his view, progress is essentially driven by research proper. However, empirical tests, which produce findings, are based not only on much thinking, but also on human, financial and technological resources, the availability of which for research institutions and research projects depends on human decisions made by authorities in power. When analyzing scientific progress, Kuhn (1962) highlights a social dimension of the process: according to him, dominant theories are those of researchers who hold power positions in the relevant academic community; as long as a generation of researchers remains in power, they tend to resist the Popperian consequences of empirical findings which contradict their theories presented by younger colleagues; when such 
findings accumulate - and as the older generation is replaced by a new one, these theories (or "paradigms") are overturned in a revolutionary process.

In its very beginning as a concept, science was considered a part of philosophy, "natural philosophy" (cf. Cahan, 2003). It gradually branched out into disciplines and sub-disciplines, some of which arose from disciplinary mergers. Again, scientific disciplines can be viewed as social groups of scientists who organize around the investigation of a part of reality under a common name for their activity, e.g. physics, linguistics, philosophy, etc. Locally and nationally, they benefit from academic structures such as research centers, faculties and departments, and from resources that academic and other authorities and organizations make available to them. This requires them to have official, 'institutional' existence through recognition by their peers and by academic authorities. Gaining recognition for disciplines such as physics, chemistry, biology, sociology, psychology and linguistics may have come naturally, but this was not the case of Translation and Interpreting Studies.

Many academics were (and still are) puzzled about the very idea of research on translation, which is often seen as unproblematic except for specialized terms and requiring no skills other than the knowledge of the relevant languages. Others believe translation is by nature an essentially linguistic activity and should be part of the territory of linguistics. Others see its relevance in literary investigations. TIS scholars have repeatedly noted and complained about a strong resistance from within departments of language and literature to the emancipation of research into translation from their academic territory (e.g. Bassnett, 1992; Lambert, personal communication; SnellHornby, personal communication).

Setting aside academic power struggles and territorial wars, some scholars who are aware of the large array of topics and research questions being investigated in connection with translation and interpreting and of the wide spectrum of very different research methods germane to them express doubts as whether technically speaking, a single disciplinary TIS entity is a good idea. Would it not make sense to continue doing and developing research into translation within more established disciplines such as linguistics and its sub-disciplines, literary studies, cultural studies, philosophy, psychology, sociology etc.? After all, this is where it is easiest to find or develop approach-specific theories and test them with the appropriate 
methods.

The case for the single TIS entity option can be made with the following two main arguments:

1. Recognizing that translation and interpreting (T\&I) have many different facets and that different disciplines which look at translation and translation-related phenomena (e.g. linguistics, psychology, neurophysiology, sociology, ethnology, comparative literature, philosophy, communication science, historiography) have foci of interest that diverge largely, they cannot be expected to systematically exchange information and engage in common projects. Federating them into a single disciplinary entity around translation should help foster such exchanges and cross-fertilization.

2. Most of the people attracted to or involved in research into T\&I are translator and interpreter trainers, who are interested in research topics around translator and interpreter training and T\&I practice. These topics tend to be marginal for researchers working from within cognate disciplines, except perhaps as regards cognitive skills acquisition and language status (e.g. bilingualism). A single TIS discipline that they can orientate to a sufficient extent so that it caters to their concerns is likely to serve them better than a situation where research on T\&I is done by outsiders, who may have a partial view of translation and fail to understand its true nature - this has been one of Seleskovitch's strong claims and reasons for wanting T\&I practitioners to take on research into translation and interpreting themselves (Widlund-Fantini, 2007).

An attempt will be made here to highlight socio-academic contributions by pioneers from the 1970s which provided to a large extent the foundations for the construction of TIS as a disciplinary entity. Today, as we advance through the 2020s, it seems reasonable to claim that their attempts have proved successful (Bassnett, 1992; Snell-Hornby, 2014), at least as regards the 'social' existence of TIS, though in terms of official recognition by academic authorities, it is still struggling - in many universities, research into T\&I is still conducted within language departments as opposed to translation and interpreting departments, and many national and international academic 
authorities still have not institutionalized TIS as an autonomous discipline. At global level, there is significant sustained research activity under the TIS banner, with thousands of papers, theses and dissertations, national and international translation studies associations (the latter include EST, the European Society for Translation Studies and IATIS, the International Association for Translation and Interpreting Studies), many specialized journals (the EST website lists more than 100 of them), dozens of Translation Studies conferences and seminars each year and hundreds of books published by major book publishers, including Benjamins, which has a dedicated Translation Studies Library collection with more than 150 published volumes, and Routledge, which has published several dedicated encyclopedias. What is also significant is that in all these publications and activities, those addressing literary and linguistic components are a minority: TIS scholars investigate and write about cognitive, technological, didactic, ethical, social and political aspects of T\&I in different professional and non-professional settings.

Causality in social behavior tends to be multifactorial. The emergence of TIS starting in the 1970s cannot be dissociated from its legacy of centuries of reflection on translation by philosophers, linguists, and practitioners of translation and interpreting, including theologians and Bible translators. There are many publications that trace back this legacy (for Western translation theory, see for instance Robinson, 1997). The modest ambition of this essay is only to highlight the importance of personal socio-academic contributions to the social organization of TIS as an academic entity.

\subsection{Leuven, CETRA and EST ${ }^{1}$}

In the early 1970s, a small group of comparative literature scholars from several European countries and Israel developed a common vision of a distinct discipline devoted to the various aspects of translation - beyond translated literature (Lambert et al., 2010). Symbolically, their action could

1 I first met Lambert in 1992. In 1993, I was appointed CERA professor, and have been associated with CE(T)RA ever since, which has given me ample opportunity to interact closely with Lambert. I also co-edited with him the first issues of the EST Newsletter. I never met Holmes. But I did attend the founding conference of EST convened in 1994, was a member of the first executive Boards, and have kept in touch with its first president Snell-Hornby. I also met with Toury many times over the years, at CE(T)RA and elsewhere. 
be said to have started with discussions in scholarly meetings and with the drafting by one of them, James Holmes, of a famous article in which he both proposed the name "Translation Studies" for the discipline - for a long time, interpreting was not acknowledged as deserving to be part of the name of the discipline - and sketched a conceptual tree-like structure mapping its various components (Holmes, 1972). According to Lambert, James Holmes was very influential in the early development of TS not because of his publications, but because of his 'social' activities. Holmes travelled widely, had many academic contacts and brought together scholars from many countries who had a similar interest in setting up a discipline devoted to research around translation and whose combined action made this possible (Lambert et al., 2010).

The history of CE(T)RA began in 1987, when Lambert, of the Katholieke Universiteit Leuven, in Belgium, founded the Penn Leuven Institute for Literary and Cultural Studies in collaboration with the University of Pennsylvania. In 1989, in the third year of the Institute, he set up in Leuven the CERA Chair for Translation, Communication and Cultures, which later became CETRA ${ }^{2}$. Every summer, a CERA chair was elected among leading scholars doing research into translation (or interpreting), 'participants' (doctoral students) were recruited, the CERA chair professor gave several lectures around his/her field of specialty, and seminars by staff members and invited lecturers were offered to the participants, who also signed up for private tutorials with them and the CERA chair professor. In the last part of the summer school, the participants gave a public presentation of their doctoral projects and received comments from the CERA professor, from staff members and from other participants. This was done over 4 weeks in the beginning years. Later, the duration of the summer school was shortened to a fortnight.

One distinct feature of the CERA summer school was its explicit will to open up TS to various approaches and paradigms, beyond the literary background of the initiators of the discipline and beyond the Descriptive Translation Studies school of thought which was clearly central for Lambert,

2 In this paper, the name CERA will be used when referring to early years of the doctoral summer school, and CE(T)RA will be used when referring to periods including this early history and later years. 
Toury and many of their students and followers (Lambert et al., 2010). Toury, the father of DTS (Descriptive Translation Studies), was the first CERA professor, but the second professor was Hans Vermeer, who advocated a very different paradigm, and the fourth professor was Gile, a conference interpreter and technical translator with no literary background. This approach has been constant ever since, with $\mathrm{CE}(\mathrm{T}) \mathrm{RA}$ professors having various backgrounds and interests, e.g. corpus linguistics, cognitive translation studies, signed language interpreting. The first members of the CERA staff all had a literary background, but this changed gradually, as new members joined, including many of the CE(T)RA professors. Participants thus had the opportunity to hear scholars from various TIS branches and schools of thought, and to discuss their personal doctoral project with them during the tutorials.

Another important feature of the $\mathrm{CE}(\mathrm{T}) \mathrm{RA}$ experience reportedly was the positive atmosphere of exchanges and friendliness for all participants, 'students', lecturers and regular members of the staff. Robyns (2018) remembers CERA as intensely exciting, an opportunity to meet people and find out how they think, to discuss one's work with interested strangers, and establish links of friendships with some of them, something "which is impossible in international conferences." Having witnessed directly the development of CE(T)RA from 1993 onwards, I believe that this atmosphere, which I also felt (also see CETRA alumni comments in the CETRA blog at https:// cetra.blog/our-alumni/) was a legacy of Lambert's mindset and supportive attitude, which seems to have been powerful enough to inspire the generations of 'students' and staff members that followed.

More importantly, perhaps, this friendly interaction within a mixed group of beginning and experienced scholars from various backgrounds and schools of thought in Translation Studies can reasonably be claimed to have strengthened, and sometimes even generated, a sense of disciplinary community (Robyns, 2018) under the 'Translation Studies' banner - in recent years, with the spectacular development of research into interpreting and the regular interaction between interpreting scholars and translation scholars, the same entity is increasingly referred to as TIS, an acronym which is adopted here - and fostered the feeling of TS being an 'interdiscipline' (Snell-Hornby et al., 1994).

In 1992, at the end of a Translation Studies congress she convened in Vienna, Mary Snell-Hornby set up the European Society for Translation 
Studies. Snell-Hornby was not part of the initial group of Leuven pioneers but shared several features with them: she also came from a literary background - though she had turned towards lexicology later - she considered that the investigation of T\&I should reach beyond literary studies or linguistics, and she was concerned about the lack of recognition of TS as a discipline and fighting for this to change. She was impressed by a 1983 conference in Exeter during which Euralex, the European Association for Lexicography was founded. She took it is a model for the 1992 Vienna Translation Studies Conference at the end of which the European Society for Translation Studies was created (personal email, April 25, 2021).

According to its Constitution, EST aims to foster research into T\&I, to promote further education for translator and interpreter trainers and offer advice on such training, and to facilitate contacts between practitioners of T\&I and relevant academic institutions (https://est-translationstudies.org/ about/). This is in tune with the spirit of CE(T)RA - Lambert was elected as a member of the first EST Executive Board and was one of the first co-editors if its Newsletter - but it also explicitly extends its reach to matters relating to translator and interpreter training, whereas $\mathrm{CE}(\mathrm{T}) \mathrm{RA}$ was and still is a doctoral school dedicated to research. This created a convenient scholarly space for the many students and trainers who were interested in research on translator and interpreter training.

The links between CE(T)RA and EST were and continued to be evident over the years: many CE(T)RA alumni joined EST and enrolled in its committees, and a vast majority of the CE(T)RA professors are also EST members - this in particular has been the case of all EST presidents so far as can be seen through the relevant lists published on the CETRA and EST websites.

$\mathrm{CE}(\mathrm{T}) \mathrm{RA}$ has now reached 32 years of existence and EST is nearly as old. Both have prospered. CE(T)RA has been the model for a number of other TIS summer schools set up later (Lambert et al., 2010). It also seems to have been the main inspiration for the international doctoral program for translation and intercultural studies set up by Anthony Pym at Universitat Rovira i Virgili in Tarragona, Spain, in 2003, which has since been absorbed by a larger entity within the university (http://www.intercultural.urv.cat/ en/research/). EST now has its own dedicated EST subseries within John Benjamin's Translation Studies Library, which, as it says in the back of the 
cover page of books in the series, should help "optimize EST's function as a forum for the translation and interpreting research community" (https:// www.jbe-platform.com/content/series/09297316). EST founder Snell-Hornby "could never dream of EST developing into what it is today...!" (Snell-Hornby, personal mail, May 2, 2021). Two success stories.

\subsection{The ESIT-Interpretive Theory Paradigm ${ }^{3}$}

The genesis and early evolution of research into T\&I at ESIT, Paris, under the drive and leadership of Danica Seleskovitch, was very atypical in the world of academia.

After earning a first degree (licence) in German and English at Sorbonne University, Seleskovitch was trained as a conference interpreter at a program attached to HEC (Ecole des Hautes Etudes Commerciales). When she graduated, in 1950, she started working as an interpreter, and a few years later, she joined AIIC, the International Association of Conference Interpreters. She was its Executive Secretary from 1959 to 1963. In the 1960s, she started writing about conference interpreting on the basis of her personal experience and observations (Widlund-Fantini, 2007). This led to a book explaining her views of conference interpreting (Seleskovitch, 1968). In 1973, she completed her $\mathrm{PhD}$ (published as Seleskovitch, 1975), and one year later, she opened a doctoral program in "translatology" at ESIT, which was part of Université Paris 3 Sorbonne Nouvelle. Her training and experience in research were very limited - according to the full list of publications provided in WidlundFantini's detailed account of her life and work (Widlund-Fantini, 2007), her only publications at that time were her 1968 book and two essays, and she was not an active member of any research group. The fact that she managed to set up within the French academic institution an autonomous doctoral program under the name of a new discipline - the first doctoral program of this kind is therefore literally extraordinary.

In a presentation made at Monterey Institute of International Studies

3 I was a conference interpreting student at ESIT from 1977 to 1979 and a student at the ESIT doctoral program from 1978 and 1979. I was thus a student of Seleskovitch - but not a disciple, as I was in disagreement with her about some aspects of Interpretive Theory and about research methodology, and completed my doctoral work elsewhere. I returned to ESIT as a professor in 2008. 
at a Training of Teachers Symposium (Seleskovitch, 1989), she explained that theoreticians that are not practitioners of translation tend to use explanations based on models derived from issues that arise in machine translation; as a result, translation practitioners consider their theories irrelevant and reject them. And yet, for training purposes, it is important to explain to students how T\&I should be done. She also stated that "translators know how things should be done, but they do not always know why", and that future teachers need to acquire relevant understanding in discussions with experienced teachers, in theoretical and didactic texts and in their own research work. She explained that these were her reasons for setting up her doctoral program. She formulated the same ideas time and again in lectures and in doctoral classes.

These explanations reflect clearly her conviction that research on interpreting (the main focus of her reflection and teaching - see Widlund-Fantini, 2007) and on translation should be carried out by practitioners, to the exclusion of linguists and psychologists. Her doctoral program was open to T\&I practitioners with an experience of at least several years. There were no classes in research methods in the one-year DEA seminar (the coursework part of the program), but lectures about T\&I were given by her and by Marianne Lederer, who completed her PhD on the simultaneous interpreting process in 1978 (published as Lederer, 1981) and is widely viewed as the co-founder of Seleskovitch's Interpretive Theory, initially known as Théorie du sens (Widlund-Fantini, 2007). More advanced doctoral students and interpreters and translators who had recently obtained the doctoral degree at ESIT also presented their ongoing work during the seminars. Students attended the lectures and presentations, read and commented on books and articles on T\&I and wrote a thesis (mémoire de DEA) before starting to work on their doctoral dissertation. Reading lists included classical essays and books on translation by authors such as Catford, Jakobson, Mounin, Vinay and Darbelnet, and references were made in class to psychologist Piaget, but not to current work in Translation Studies by anyone from the Leuven group, by German functionalists (Vermeer, Nord and others), by Ghelly Chernov and others in Russia, or more generally by any competing school of thought on translation or by cognitive psychologists and psycholinguists working on simultaneous interpreting at that time - this was at least the case in the academic year 1978/1979, during which I attended the doctoral program at 
ESIT, and reportedly, no major changes occurred until much later.

Widlund-Fantini (2007) reports that Seleskovitch cooperated with Jacques Barbizet, a French neuropsychologist, and Seleskovitch, Lederer and other interpreter trainers representing the same school of thought participated in a conference convened by cognitive psychologists (Gerver \& Sinaiko, 1978), but this resulted in no further interaction (see Pöchhacker, 2004, p. 69; Widlund-Fantini, 2007, pp. 158-159), and virtually no references to them can be found in publications of what became known as the 'Paris School'.

Thus, the doctoral program at ESIT as well as research conducted around it could be characterized as exclusive and focused (around training, including cognitive issues relevant to training), whereas the Leuven-CETRA-EST philosophy was inclusive.

Seleskovitch's doctoral program attracted many candidates from all over the world, perhaps largely because it was the first of its kind, was offered by a school which had the reputation of having an excellent training program for conference interpreters and translators, and because it was led by Seleskovitch, who was well-known as a conference interpreter and interpreter educator.

The program has not fared well in institutional terms. It eventually lost its accreditation as an Ecole doctorale within the university and is now part of a linguistics Ecole doctorale. However, in terms of productivity and reputation, it was quite successful during the first decades of its existence. Within ten years from its creation, 14 doctoral dissertations were completed, all supervised by Seleskovitch, who was later joined by Lederer and Israël (see the list of completed dissertations at http://www.univ-paris3.fr/les-theses-de-doctorat-esittraductologie-47923.kjsp). Students from Africa, Canada, China, Korea and the USA then disseminated Interpretive Theory and its outlook on translation, interpreting and TS in their respective countries. Some of them gained prominent status in their home countries, which gave them more power as ambassadors of the 'Paris school' (Widlund-Fantini, 2007). Moreover, when needs for translator and interpreter training arose in various parts of the world and requests arrived to the French ministry of foreign affairs, trainers from ESIT were regularly sent to help out, which also helped spread the ESIT paradigm. Interpretive Theory became well-known worldwide and is still very popular among interpreting trainers and students (Xu, 2014; Kleibs, 2018), though its position among theoreticians and empirical researchers working on T\&I has 
weakened markedly; ESIT authors were often cited in the 1980s and 1990s, but much less frequently since the end of the 1990s, even in the Interpreting Studies branch, in which their influence was strongest. This is not surprising in a paradigm made of "personal theories" (Gile, 1990), i.e. theories that are constructed on the sole basis of observations and reflections by practitioners (Widlund-Fantini, 2007), with virtually no self-critical empirical testing and very little engagement with theories and findings from relevant cognate disciplines and competing TIS-internal schools of thought. Even some former students of Seleskovitch now point out weaknesses in some of its claims, including the very central concept of "deverbalization" (Widlund-Fantini, 2007). Nevertheless, Seleskovitch's efforts have succeeded remarkably in two respects. One is the lasting popularity of Interpretive Theory as a conceptual basis for interpreter training. The other is the indisputable fact that Seleskovitch created a novel research space which has attracted many trainers and practitioners who did not initially plan to do research into translation or interpreting - including the author of these lines.

\section{A Japanese Learned Society: JAITS, the Japan Association for Interpreting and Translation Studies ${ }^{4}$}

In the first case study described here, the initiative for action came from a group within the academic community. In the second case, it came from one practitioner-cum-trainer who decided to set up a distinct research space against the background of a perceived need for theory to corroborate intuitions derived from the observation of practice (Seleskovitch, 1975; Widlund-Fantini, 2007). The context and motivation that led to the foundation of a learned society dedicated to interpreting in Japan were different.

Masaomi Kondo, a conference interpreter, was one of the few Japanese AIIC members in the 1980s. He also taught economics at Daito Bunka University in Tokyo and trained interpreters, but did not engage in research into interpreting. He reports (Kondo, 2009) that when he attended a seminar

4 I first met Masaomi Kondo in 1985, while I was staying in Japan for a research scholarship. I stayed in touch with him, saw the founding of IRAJ, then of JAIS/JAITS, of which I am an honorary member. 
convened by the Monterey Institute for International Studies in 1989, he was struck by the "discovery" of the existence of academic literature on interpreting in Europe and of postgraduate interpreter training programs in the Asia-Pacific region which offered Japanese in their language combinations. By contrast, in Japan, most of the literature on interpreting "merely described the careers of individual interpreters in anecdotal fashion" - see an overview of the literature in Japan in the mid-1980s in Gile (1988). In view of the low social status of interpreting in Japan, he considered that it was "imperative for Japanese interpreters to become part and parcel of this new area of research", and set out to initiate such research "without much optimism" (Kondo, 2009). In 1990, with Nobutaka Miura, he established IRAJ, the Interpreting Research Association of Japan (通訳理論研究会). The twelve founding members met once a month "to report on an area of European studies", to discuss training methods in various interpreter training programs in Europe and elsewhere and to exchange information on training and research. They also decided to publish a journal; the first issue of Interpreting Research (通訳理論研究) was printed in July 1991. Over 10 years, the Association published seventeen issues of the journal. Meanwhile, membership of the group rose from 12 to about 80 members, with an increasing number of academics. The journal started to publish papers on various interpreting settings and extended the range of publications to written translation. In 2008, the Association was renamed (Japan Association for Interpreting and Translation Studies, '日本通訳翻 訳学会') and the journal was renamed (Interpreting and Translation Studies, 通 訳翻訳理論研究). The Association now has a membership of several hundred people and successfully holds large annual Congresses.

Again, the initiative of a single individual who was not a researcher himself led to the birth of a flourishing learned society and probably had a major effect on the development of the Japanese TIS research community this needs to be documented through an in-depth study from within Japan, perhaps along the lines of the investigations being carried out in Korea by Lee (2015) and Lee and Nam (2019). Noteworthy is the fact that most JAITS members publish their research in Japanese and either in their association's journal, or in Japanese university journals. Only rarely do they venture into the international research literature (but see Torikai, 2009; Someya, 2016; Matsushita, 2019). 


\section{Other Socio-academic Contributions That Matter}

In the previous sections, two international and one national socio-academic creations were described and commented. In order to better grasp the mechanisms underlying and influencing socio-academic creations in TIS, it would be necessary to undertake comprehensive investigations of other cases of creation of national learned societies, translation and interpreting journals and specialized doctoral programs dedicated to T\&I where individual initiative may have been far more important than institutional action. The analysis of Lee (2015) and Lee and Nam (2019) suggest that Korea, where TIS is particularly lively, would be an interesting case.

In the next two sections, I will limit myself to some comments about other important functions that socio-academic contributions can perform to help ensure long-term sustainability of the discipline.

\subsection{Breaking Isolation by Fostering Face-to-face and Online Interaction}

Translation is systematically taught in some form as part of foreign language training, and foreign languages are widely taught in universities across the world. It would thus seem natural to expect the TIS community to be large in any country. However, judging by the authorship of articles published in TIS journals, this is not the case. Part of the reason may be the fact that many teachers of translation in foreign language and culture departments are not professional translators, and their academic interests are linked to language per se, to literature, to history or more generally to cultural issues rather than to translation as such. As to teachers in translator and interpreter training programs, most are practitioners and their interests tend to be remote from 'theory' (to illustrate this rift, see Chesterman \& Wagner, 2002). The TIS population is relatively large in some countries such as Spain, where translation schools were 'academized' in the 1990s (see MEC, 1991), with research requirements from both students and staff. It is very large in China, where the government created the Bachelor of Translation and Interpreting (BTI) and Master's of Translation and Interpreting (MTI) in hundreds of universities (see Xu, 2014), but it is small in many other countries, and as regards certain TIS branches, e.g. interpreting, including conference interpreting, community interpreting 
and signed language interpreting, cognitive translation studies, corpus-based translation studies, or audio-visual translation studies, TIS scholars find themselves with few or no colleagues to interact with in their local or even national academic environment. This is a threat to the long-term survival of the discipline through loss of motivation.

Congresses, colloquia and other exchanges organized by academic entities and national and international learned societies are part of the answer to the problem. Until the Covid epidemic, such fora depended on heavy funding and organization. Somewhat ironically, the Covid epidemic has fostered the organization of online meetings and lectures, which are far less costly and have become numerous. So have online lectures by speakers from overseas. This can make the socio-academic contribution of individual colleagues who take the initiative to convene and/or organize such events particularly valuable for the discipline, even if their 'technical' academic stature in terms of theoretical and/or empirical contributions is modest.

\subsection{Fostering TIS Population Renewal in Translator and Interpreter Training Programs}

One critical requirement for any academic discipline is the constant renewal of its population: when researchers retire, they need to be replaced. In some branches of TIS such as literary translation or translation history or even translation linguistics which are associated with scholarly activity, such 'natural' renewal from within the ranks of academia can be expected. But demographically speaking, in TIS, these branches have become relatively marginal, and judging by biographies available on the Worldwide Web and in some journals and collective volumes, most authors of TIS research seem to come from translator and interpreter training programs - though a systematic study of TIS demographics is yet to be conducted. In such environments, students enroll with a view to acquire professional skills, not academic skills, and trainers are entrusted with the task of helping them attain this objective. For this reason, in the most prestigious training programs (in Europe, ETI in Geneva and ESIT in Paris are two of them) the teaching staff is composed mostly of non-tenured professionals who are neither trained nor interested in research. In such an unfavorable environment for the demographic renewal of TIS, the attitude and personality of supervisors of theses and dissertation 
play a critical role in creating and upholding motivation for research among students. The best evidence for the effect of such variables would come from ethnographic investigations among doctoral students and young researchers, but such investigations have yet to be undertaken. At this point, I can only offer personal impressions and anecdotal evidence from participation in doctoral schools and seminars and in meetings between supervisors and students and from conversations with both. In such meetings and conversations, the role of supportive, personal interest in the student's work and well-being by advisors and supervisors beyond their technical guidance function seems to be a powerful incentive and helps students overcome the all-too-frequent 'doctoral blues' which cause so many to drop out.

\section{From the Past to the Future}

This essay is devoted to the socio-academic side of the emergence and development of TIS. However, the core of academic disciplines is research, and some features of TIS research need to be addressed if only briefly in order to gain better understanding of the past (short) history of the discipline and of possibilities for future evolution.

While Holmes (1972) saw Translation Studies as an empirical discipline, few empirical studies were published during the early history of TIS. Pioneers who came from comparative literature tended to write theoretical texts. As to those who came from the world of translation and interpreting practice, most of them wrote prescriptive texts and essays. Publications that would meet the usual requirements of empirical research in science as enforced in peerreviewed journals were rare - generally, they resulted from work of students under the supervision of researchers from cognate disciplines - as was the case at the SSLMIT of the University of Trieste (see for example Gran \& Taylor, 1990). There was thus a gap between the level of scholarship of academics who had migrated from other disciplines in the humanities having been trained as scholars in their mother discipline on one hand, and of newcomers who had not been socialized into the norms of scientific research on the other. This was not favorable to recognition of TS as an academic discipline. Over the years, the situation has improved spectacularly, as interest in empirical research grew, training in research methods was provided in many 
translator and interpreter training programs, and journals started to select manuscripts with more stringent peer-reviewing. Incidentally, most doctoral projects now presented at CETRA are empirical, and staff members with a literary background thus have an opportunity to become familiar with the relevant research methods.

It seems safe to say that overall, in spite of the persistence of methodological weaknesses in many publications (see the comments in the successive issues of the CIRIN Bulletin at https://cirin-gile.fr), TIS now has a body of serious scholarly work which is expanding every year.

But will it continue to exist as a disciplinary entity? As stated earlier, a large proportion of its population comes from translator and interpreter training programs, and these are most often part of or attached to foreign language departments, which, in turn, may have close links with linguistics and psycholinguistics departments against the background of bilingualism and foreign language acquisition. There is a distinct possibility that in the future, institutional and economic conditions, including academic positions and funds for research projects, will make it more convenient to investigate T\&I within linguistics, psychology, sociology, philosophy, comparative literature, history, communication science, education science and so on, which would undermine the disciplinary existence of TIS. If this were to happen, it is to be hoped that collective memory of what has been gained by the extant disciplinary entity since its emergence thanks to the socioacademic contributions of the pioneers will foster regular interdisciplinary collaboration in the quest for cross-fertilization.

\section{References}

Bassnett, Susan. (1992). Translation Studies (Rev. ed.). Routledge.

Cameron, Brian D. (2005). Trends in the use of ISI bibliometric data: Uses, abuses and implications. portal: Libraries and the Academy, 5(1), 105-125.

Cahan, David (Ed.). (2003). From Natural Philosophy to the Sciences: Writing the History of Nineteenth-Century Science. University of Chicago Press.

Chesterman, Andrew and Emma Wagner. (2002). Can Theory Help Translators? A Dialogue between the Ivory Tower and the Wordface. St. Jerome Publishing.

Gerver, David and H. Wallace Sinaiko (Eds.). (1978). Language Interpretation and 
Communication: Proceedings of the NATO Symposium, Venice, Italy, September 26 October 1, 1977. Plenum Press.

Gile, Daniel. (1996). La formation à la recherche traductologique et le concept CERA Chair [Training Translation and Interpreting Studies researchers and the CERA Chair concept]. Meta, 41(3), 486-490.

Gile, Daniel. (1994). Opening up in interpretation studies. In Mary Snell-Hornby, Franz Pöchhacker \& Klaus Kaindl (Eds.), Translation Studies: An interdiscipline (pp. 149-158). John Benjamins.

Gile, Daniel. (1990). Scientific research vs. personal theories in the investigation of interpretation. In Laura Gran \& Christopher Taylor (Eds.), Aspects of Applied and Experimental Research on Conference Interpretation (pp. 28-41). Campanotto.

Gile, Daniel. (1988). Les publications japonaises sur la traduction : Un aperçu [An overview of Japanese publications on translation]. Meta, 33(1), 115-126.

Gran, Laura and Christopher Taylor (Eds.). (1990). Aspects of Applied and Experimental Research on Conference Interpretation. Campanotto Editore.

Grinev, Andrei. (2021). Quartile index. Academia Letters, Article 663. https://doi.org/10.20935/ AL663

Holmes, James. (1972). The name and nature of translation studies [Unpublished manuscript]. (Reprinted in Translation Across Cultures by Gideon Toury, Ed., 1987, Bahri Publications; reprinted in The Translation Studies Reader, pp. 172-185, by Lawrence Venuti, Ed., 2000, Routledge)

Kleibs, Frauke. (2018). Die wahrnehmung der rolle von theorie in der ausbildung von konferenzdolmetscherInnen. Eine explorative studie [The perception of the role of theory in the training of conference interpreters. An exploratory study] [MA thesis]. Institut für Angewandte Linguistik und Translatologie der Universität Leipzig.

Kondo, Masaomi. (2009, June 22). Genesis of the Japan association for interpretation studies (JAIS). AIIC Bulletin.

Kuhn, Thomas. (1962). The Structure of Scientific Revolutions (1st ed.). University of Chicago Press.

Lambert, José, Gustavo Althoff and Lilian Fleuri. (2010). Interview with José Lambert. Scientia Traductionis, 7, 207-234.

Lederer, Marianne. (1981). La traduction simultanée : expérience et théorie [Simultaneous translation: Experience and theory]. Lettres modernes, Minard.

Lee, Hyang. (2015). Mapping translation studies in Korea using the Holmes map of translation studies. Forum, 13(1), 65-86.

Lee, Hyang and Won Jun Nam. (2019). The past and future of translation studies in South 
Korea. Perspectives, 27(3), 419-430.

Matsushita, Kayo. (2019). When News Travels East. Translation Practices by Japanese Newspapers. Leuven University Press.

MEC (Ministerio de Educación y Ciencia). (1991). Real Decreto 1385/1881 [Royal Decree 1385/1881]. Boletín Oficial del Estado, 234, 31773-31775.

Merton, Robert K. (1973). The Sociology of Science. Theoretical and Empirical Investigations. The University of Chicago Press.

Moed, Henk and Gali Halevi. (2015). Multidimensional assessment of scholarly research impact. Journal of the Association for Information Science and Technology, 66(10), 19882002.

Pöchhacker, Franz. (2004). Introducing Interpreting Studies. Routledge.

Popper, Karl. (1959/2002). The Logic of Scientific Discovery. Routledge.

Robinson, Douglas. (1997). Western Translation Theory. From Herodotus to Nietzsche. St. Jerome Publishing.

Robyns, Clem. (2018). An alternative history of the Summer School's first years. A speech by Clem Robyns, Participant of the $1^{\text {st }}$ Summer School in 1989. https://cetra.blog/2018/09/14/ an-alternative-history-of-the-summer-schools-first-years-a-speech--by-clem-robynsparticipant-of-the-1st-summer-school-in-1989/

Seleskovitch, Danica. (1989, December 1-3). Theory in the training of translation teachers. In Wilhelm K. Weber (Ed.), Twentieth Anniversary Symposium: The Training of Teachers of Translation and Interpretation (pp. 84-96). Monterey Institute of International Studies.

Seleskovitch, Danica. (1975). Langage, langues et mémoire [Language, languages and memory]. Lettres Modernes, Minard.

Seleskovitch, Danica. (1968). L'interprète dans les conférences internationales. Problèmes de langage et de communication [Interpreting for international conferences: Problems of language and communication]. Lettres Modernes, Minard.

Snell-Hornby, Mary. (2014). EST 2012 - A vision fulfilled?. Target, 26(2), 239-245.

Snell-Horny, Mary, Franz Pöchhacker and Klaus Kaindl (Eds.). (1994). Translation Studies: An Interdiscipline. John Benjamins.

Someya, Yasumasa. (Ed.) (2016). Consecutive Notetaking and Interpreter Training. Routledge.

Torikai, Kumiko. (2009). Voices of the invisible presence. Diplomatic Interpreters in Post-War Japan. John Benjamins.

Venuti, Lawrence (Ed.). (2000). The Translation Studies Reader. Routledge.

Widlund-Fantini, Anne-Marie. (2007). Danica Seleskovitch. Interprète et témoin du XXe siècle [Danica Seleskovitch, a conference interpreter and witness to the twentieth century]. L'Age d'Homme. 
58 Daniel Gile

Xu, Ziyun. (2014). Chinese interpreting studies: Genesis of a discipline. Forum, 12(2), 159-190.

Websites:

CETRA: https://www.arts.kuleuven.be/cetra/

CIRIN: https://cirin-gile.fr

EST - European Society for Translation Studies: https://est-translationstudies.org/

Intercultural Studies Group, Universitat Rovira i Virgili: http://www.intercultural.urv.cat/en/ research/

John Benjamins Translation Library: https://www.jbe-platform.com/content/series/09297316

Université Paris 3 Sorbonne Nouvelle, ESIT doctoral dissertations: http://www.univ-paris3.fr/ les-theses-de-doctorat-esit-traductologie-47923.kjsp

\section{Professional Profile}

Daniel Gile migrated from mathematics and sociology to translation and conference interpreting and, in parallel, to academia. Besides degrees from his initial studies, he holds a $\mathrm{PhD}$ in Japanese, a PhD in linguistics, and a post-doctoral habilitation degree, all related to translation and/or interpreting. He is now Professor Emeritus at Université Paris SorbonneNouvelle. He has lectured and traveled widely, and is the author of more than 250 publications on translation and interpreting, including the monograph Basic Concepts and Models for Interpreter Training (for further details, see https://cirin-gile.fr). 